\title{
Insecticidal and growth inhibiting action of the supercritical extracts of Melia azedarach on Spodoptera frugiperda
} \author{
Rivaldo Niero ${ }^{5} \&$ Jacir Dal Magro ${ }^{6}$

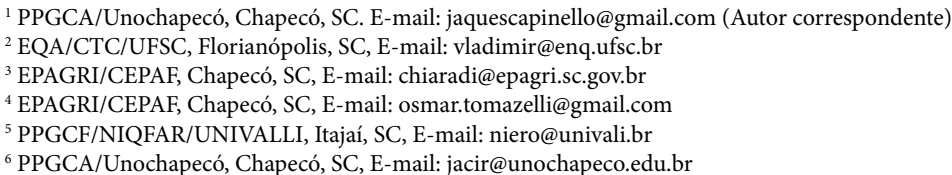

Jaqueline Scapinello ${ }^{1}$, José V. de Oliveira ${ }^{2}$, Luis A. Chiaradia ${ }^{3}$, Osmar Tomazelli Junior ${ }^{4}$,

\section{Key words:}

supercritical extraction

fall armyworm

chinaberry

\begin{abstract}
A B S T R A C T
This study evaluates the effects of supercritical carbon dioxide extracts obtained from the fruit of Melia azedarach L. (Meliaceae) on the development of Spodoptera frugiperda J.E. Smith, 1797 (Lepidoptera: Noctuidae), from the larval period until the insect adulthood. For this purpose, a laboratory-scale extraction unit was operated at $60{ }^{\circ} \mathrm{C}$ and 200 bar. Larval mortality increased by raising the extract concentration tested: the value of $\mathrm{LC}_{50}$ calculated by Probit analysis was $376.74 \mathrm{mg} \mathrm{kg}^{-1}$, and at a concentration of $5000 \mathrm{mg} \mathrm{kg}^{-1}$, the mortality was $100 \%$. The extract exhibited insect growth inhibitory activity in the higher concentrations $\left(500 \mathrm{mg} \mathrm{kg}^{-1}, 1000 \mathrm{mg} \mathrm{kg}^{-1}\right.$ and $5000 \mathrm{mg} \mathrm{kg}^{-1}$ ), due to antifeedant action, resulting in larvae and pupae with mass and body length significantly smaller than the control. At the lowest concentration tested $\left(100 \mathrm{mg} \mathrm{kg}^{-1}\right)$, bioactive effects from the adult stage of the insect were observed, with low viability pupal and adults presenting morphological deformities, hence indicating chronic toxicity effect.
\end{abstract}

Palavras-chave: extração supercrítica lagarta-do-cartucho cinamomo

\section{Ação inseticida e inibitória de crescimento de extratos supercríticos de Melia azedarach sobre Spodoptera frugiperda}

\begin{abstract}
R E S U M O
Este estudo avaliou os efeitos do extrato de frutos de Melia azedarach L. (Meliaceae) obtido através do solvente dióxido de carbono supercrítico sobre o desenvolvimento de Spodoptera frugiperda J.E. Smith, 1797 (Lepidoptera: Noctuidae), desde o período larval até a fase adulta do inseto. Para obtenção do extrato, uma unidade de extração em escala laboratorial foi operada a $60^{\circ} \mathrm{C}$ e 200 bar. O extrato, quando adicionado à dieta artificial das larvas, demonstrou ação inseticida, a CL50 calculada através da análise de Probit foi de 376,74 $\mathrm{mg} \mathrm{kg}^{-1}$, na concentração de $5000 \mathrm{mg} \mathrm{kg}^{-1}$ e a mortalidade foi de $100 \%$. Nas concentrações mais elevadas (500, 1000 e $5000 \mathrm{mg} \mathrm{kg}^{-1}$ ) o extrato apresentou também atividade inibitória de crescimento nos insetos, devido à ação antialimentar, resultando em larvas e pupas com massa e comprimento corporal significativamente menores que o controle. Na menor concentração testada $\left(100 \mathrm{mg} \mathrm{kg}^{-1}\right)$ foram observados efeitos bioativos a partir da fase adulta do inseto, como baixa viabilidade de pupas e adultos com deformações morfológicas, indicando, portanto, efeito de toxicidade crônica.
\end{abstract}

\section{INTRODUCTION}

Ensuring acceptable productivity indices that provide economic returns to agricultural activity, the application of high amounts of pesticides is commonly required, generating intense and continuous contamination of natural resources, risks to the human health and biodiversity degeneracy (Pedlowski et al., 2012). To reduce the consumption of these chemicals, new methods of insect control in agriculture has been investigated over the last years, along with a search for management of chemicals with a lower environmental impact.
Plants generally produce a variety of compounds that have important ecological role in regulating interactions among plants, microorganisms, insects and other animals. To protect themselves from predators, plants synthesize defensive substances with toxic properties or create inhibitory conditions for the development of pathogens (Wittstock \& Gershenzon, 2002). The increasing interest in the possible application of these substances to fight against insects and diseases that affect food production resulted in the search for new biopesticides formulations (Isman, 2005). 
The chinaberry tree, Melia azedarach L. (Meliaceae), has been known for thousands of years due to its insecticidal properties, which are related to the presence of limonoids, compounds of the class of terpenes, in large quantities and in all plant structures, with the limonoids of $\mathrm{C}$-secoskeleton ring reported as being the most active (Bohnenstengel et al., 1999), as the terpenes azadirachtin, melianone (Lavie et al., 1966) and 1-cinnamoylmelianolone (Lee et al., 1987).

Many effects have been attributed to M. azedarach, such as repellence, antifeedant effects, developmental delay and halting of ecdysis, reduction of fertility and fecundity, behavioral and physiological changes leading to possible mortality (Defagó et al., 2006; Nathan, 2006; Bullangpoti et al., 2012).

The manifestation of the effects and the reaction time are always a function of the dose used and the exposure time (Carpinella et al., 2006), in addition to the plant structure used and the extraction method used. Supercritical carbon dioxide is a promising alternative for the extraction method to obtain pure (solvent-free) extracts with the use of a cheap, readily available, non-toxic, non-flammable, green-solvent by manipulating the system temperature and the pressure near the solvent critical point, hence finely tuning the thermodynamic and transport properties to produce rich-bioactive compounds extracts (Nahar \& Sarker, 2006). Furthermore, it has been reported that many of the insecticidal substances derived from plants usually have high solubility in carbon dioxide $\left(\mathrm{SC}-\mathrm{CO}_{2}\right)$ (Reverchon \& Marco, 2006).

In this context, the aim of this study was to evaluate the effects of the fruit extract of $M$. azedarach obtained by the extraction using supercritical $\mathrm{CO}_{2}$ on the development of $S$. frugiperda, from the larval period until the insect adulthood.

\section{Material AND Methods}

Samples of the fruit of M. azedarach were collected during the summer of 2012 (February), when the color of the fruit was light green and the fruit exhibited a smooth epidermis, in the municipality of Chapecó located in the South of Brazil $\left(27^{\circ} 05^{\prime} \mathrm{S}, 52^{\circ} 40^{\prime} \mathrm{W}\right)$. Voucher specimens were deposited at the Herbarium of Universidade Comunitária da Região de Chapecó (Herbarium Unochapecó) with the accession numbers: UNO 2841. Plant material (fruit) was dried at $40{ }^{\circ} \mathrm{C}$ for two days and then milled to $20 \mathrm{mesh}$. The samples were then stored at a room temperature under nitrogen atmosphere prior to the extraction.

Carbon dioxide ( $99.9 \%$ purity in the liquid phase) was kindly provided by White Martins S.A. The experimental extraction apparatus and procedure was described in detail in other studies (Rodrigues et al., 2004; Jacques et al., 2007). Briefly, the experiments were performed in a laboratory scale unit, which consists basically of a $\mathrm{CO}_{2}$ reservoir, two thermostatic baths, a syringe pump (ISCO 260D), a $0.518 \mathrm{~L}$ jacketed extraction vessel, an absolute pressure transducer (Smar, LD301) equipped with a portable programmer (Smar, HT 201) with a precision of \pm 0.12 bar, a collector vessel with a glass tube and a cold trap. The amounts of $70.03 \pm 0.09 \mathrm{~g}$ of dried and powdered fruit were charged into the extraction vessel. The $\mathrm{CO}_{2}$ was pumped into the bed, which was held by two 300 mesh wire disks in both ends, and was kept in contact with the sample matrix for at least $1 \mathrm{~h}$ to guarantee the system stabilization under the same conditions of the experiment.

Afterwards, the essential oil was collected by opening the micro-metering valve and the $\mathrm{CO}_{2}$ mass flow was taken into account in the pump recordings. The experiments were accomplished isothermally, at $60^{\circ} \mathrm{C}$ and constant pressure, 250 bar, using a mass $\mathrm{CO}_{2}$ flow rate of $2 \mathrm{~g} \mathrm{~min}^{-1}$ over $2 \mathrm{~h}$. These conditions were selected after execution of a full $2^{2}$ factorial experimental design, considering as the main variable the extraction temperature in the range of $40-60{ }^{\circ} \mathrm{C}$ and the pressure from 150 to $250 \mathrm{bar}$, which resulted in the maximum extraction yield together with the content of oxygenated terpenes fraction in the extract, with limonoids as the main target components. Under these extraction conditions, the extraction yield $(\%, \mathrm{w} / \mathrm{w})$ after triplicate experiments was found to be $5.41 \pm 0.11 \%$. The extraction yield is defined here as the weight percentage of the oil extracted with respect to the initial charge of the raw material in the extractor.

For isolating compounds from the fruit of M. azedarach, the plant material (total mass $600.34 \mathrm{~g}$ ) was dried at a temperature of $40{ }^{\circ} \mathrm{C}$ and then macerated with ethanol and concentrated under vacuum rotatory evaporator, obtaining $27.87 \mathrm{~g}$ of crude chinaberry ethanolic extract (CEE). The CEE (15.0 g) was fractionated on chromatographic column over Silica gel 60 (Merck). The eluents of hexane, dichloromethane (DCM), ethyl acetate (EA) and ethanol were used in a gradient to increase the polarity. By elution with DCM/AE (60/40), 34.0 mg was obtained, the components of which were identified by spectroscopic data (IR, ${ }^{1} \mathrm{H}$ and ${ }^{13} \mathrm{C}$ NMR, MS) and compared with the literature values (Lavie et al., 1966; Ntalli et al., 2010).

The phytochemical screening of the extract $\mathrm{SC}-\mathrm{CO}_{2}$ was accomplished as described by Harbore (1998) by observing the colorimetric variation after the addition of specific reagents in silica gel plates $60 \mathrm{~F}_{254}$ (Merck). The main phytochemicals analysed were terpenes, sterols, flavonoids, alkaloids, coumarins and tannins.

ESI-Q-TOFMS measurements were performed using a micrOTOF Q-II (Bruker Daltonics) mass spectrometer equipped with an automatic syringe pump from KD Scientific for sample injection. The ESI-QTOF mass spectrometer was operated at $4.5 \mathrm{kV}$ and at a desolvation temperature of 180 ${ }^{\circ} \mathrm{C}$. The mass spectrometer was operating in the positive ion mode. The standard electrospray ion (ESI) source was used to generate the ions. The sample was injected using a constant flow $(3 \mu \mathrm{L} \mathrm{min}-1)$. The solvent was an acetonitrile/methanol mixture. The ESI-Q-TOF MS instrument was calibrated in the range of 50 to $3000 \mathrm{~m} \mathrm{z}^{-1}$ using an internal calibration standard (Low concentration tuning mix solution), which was supplied by AgilentTechnologies. Data were processed via Bruker Data Analysis software version 4.0.

The artificial diet used in the experiment was prepared as described by Greene et al. (1976). For the extract addition, the diet was divided into five equal portions, one being the control, without addition of the extract, and the other four received 
different doses of the extract, at concentrations of 100, 500, 1000 and $5000 \mathrm{mg} \mathrm{kg}^{-1}$. The diet was offered to larvae of $S$. frugiperda, seven days old; the larvae had an average length of $0.65 \mathrm{~cm}( \pm 0.05)$ and a weight of $2.72 \mathrm{mg}( \pm 0.37)$. The larvae were kept individually in capped plastic containers $(80 \mathrm{~mL})$ at a temperature of $25{ }^{\circ} \mathrm{C}( \pm 0.5)$. The experimental design was completely randomized. In each treatment, 10 larvae, in four replicates were used.

In each treatment, development of the larvae was observed by recording the body weight and length of each larva and the number of dead larvae, twice a week. The mortality of larvae was corrected by the Abbott equation that compares the effect of treatments with natural mortality that occurs in the control plots (Heong et al., 2011).

The larval period was estimated for insects surviving to the pupa stage, considering the number of days since the implementation of the experiment until the day of observation of the pupa. From the emergence of the moths, it was possible to obtain the percentage of viable pupae and the sex ratio in each treatment.

\section{Results AND Discussion}

Phytochemical analysis of the SC- $\mathrm{CO}_{2}$ extract of the fruit of $M$. azedarach revealed the presence of compounds from the class of terpenes, sterols and coumarins, highlighting the presence of the class terpenes compounds, which are associated with the insecticidal effects on the insects. The analysis of ESI-Q-TOFMS determined the presence of the compound melianonein SC-CO $\mathrm{CO}_{2}$ extract (Figure 1), which is reported as the major constituent of M. azedarach (Polonsky et al., 1977).
In the spectral measurements, this compound exhibited an ion $[\mathrm{M}+\mathrm{Na}]^{+} 493.3 \mathrm{~m} \mathrm{z}^{-1}$.

The viability of larval $S$. frugiperda was significantly altered by the presence of the supercritical extract of the fruit of $M$. azedarach in an artificial diet. All of the extract concentrations investigated exhibited significant differences between the means in relation to the control treatment, with a reduction in the viability proportional to the increasing concentration of the extract added to the diet (Table 1). These results confirm the insecticidal activity of M. azedarach, as reported for other lepidopterans, including Cnaphalocrocis medinalis (Guenée, 1854) (Lepidoptera: Crambidae) (Nathan, 2006), Spodoptera eridania (Cramer) (Lepidoptera: Noctuidae) (Rossetti et al., 2008), Plutella xylostella L., 1758 (Lepidoptera: Plutellidae) (Dequech et al., 2009) and Tuta absoluta Meyrick, 1917 (Lepidoptera: Gelechiidae) (Brunherotto et al., 2010).

None of the larvae of the treatment with $5000 \mathrm{mg} \mathrm{kg}^{-1}$ completed the larval stage. The mortality in this treatment was significant since the beginning of the experiment, reaching

Table 1. Duration and larval viability of Spodoptera frugiperda (Lepidoptera: Noctuidae) fed an artificial diet containing the SC-CO 2 extract of the fruit of Melia azedarach (Meliaceae)

\begin{tabular}{cccc}
\hline Concentration & \multirow{2}{*}{$\begin{array}{c}\text { Duration } \\
\left.\text { (mg kg } \mathbf{~}^{-1}\right)\end{array}$} & (days) & \multicolumn{2}{c}{ Viability } & CM \\
\cline { 3 - 4 } Control & $18.35 \pm 1.78 \mathrm{a}$ & $82.5 \pm 5.00 \mathrm{a}$ & - \\
100 & $18.39 \pm 2.13 \mathrm{a}$ & $65.0 \pm 5.75 \mathrm{~b}$ & 21.21 \\
500 & $20.16 \pm 2.97 \mathrm{a}$ & $42.5 \pm 5.00 \mathrm{c}$ & 48.48 \\
1000 & $24.86 \pm 5.36 \mathrm{~b}$ & $35.0 \pm 5.77 \mathrm{c}$ & 57.58 \\
5000 & - & $0.0^{\mathrm{d}}$ & 100.00 \\
\hline
\end{tabular}

Values followed by the same letter in columns do not differ according to the Tukey test at a probability level of 0.05 . CM - Corrected mortality Abbott Equation (Heong et al., 2011)

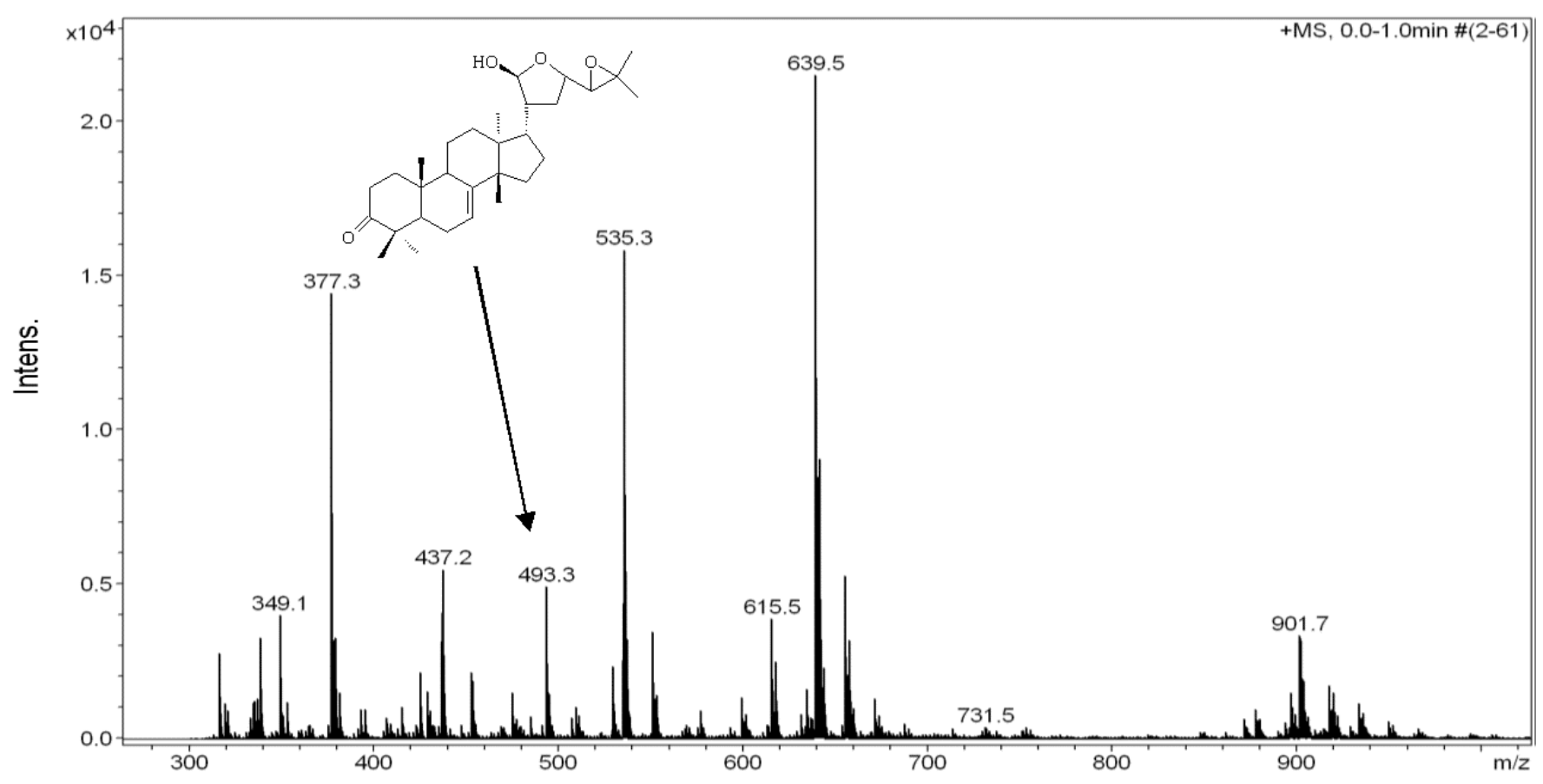

The position of the peak for melianone $[\mathrm{M}+\mathrm{Na}]^{+}\left(493.3 \mathrm{~m} \mathrm{z}^{-1}\right)$ is indicated by the arrow

Figure 1. Mass spectrum of the extract $\mathrm{SC}-\mathrm{CO}_{2}$ of the fruit of Melia azedarach (Meliaceae) exhibiting the presence of triterpene melianone as determined by ESI-Q-TOF-MS analysis 
$100 \%$ after 30 days (Figure 2). The concentration of 376.74 $\mathrm{mg} \mathrm{kg}^{-1}$ was found to be the $50 \%$ mortality level of $S$. frugiperda $\left(\mathrm{LC}_{50}\right)$ exposed to the extract $\mathrm{SC}-\mathrm{CO}_{2}$ of $M$. azedarach during the larva stage.

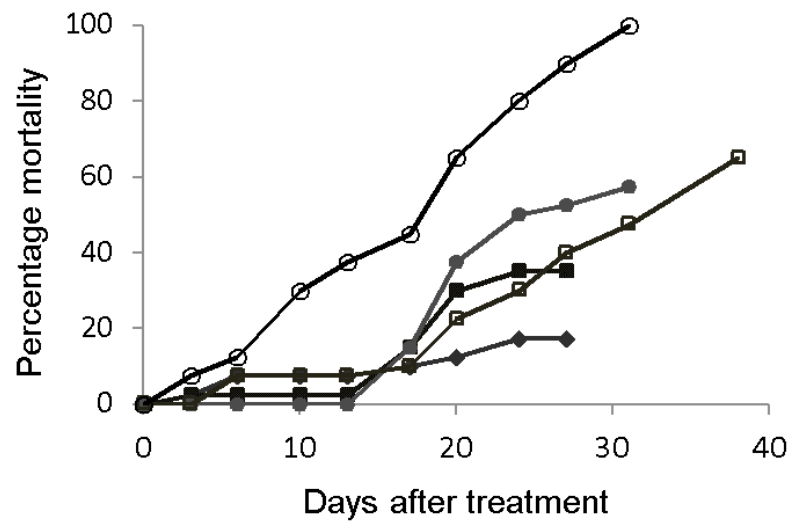

- - control; - - $100 \mathrm{mg} \mathrm{kg}^{-1} ;-\bullet-500 \mathrm{mg} \mathrm{kg}^{-1} ;-\square-1000 \mathrm{mg} \mathrm{kg}^{-1} ;-\circ-5000 \mathrm{mg} \mathrm{kg}^{-1}$

Figure 2. Percentage mortality of the larvae of Spodoptera frugiperda (Lepidoptera: Noctuidae) fed an artificial diet containing the $\mathrm{SC}-\mathrm{CO}_{2}$ extract of Melia Azedarach (Meliaceae)

For the insects survivors treated with $1000 \mathrm{mg} \mathrm{kg}^{-1}$ of extract, the expansion of the larval period compared to the control treatment was observed. The prolonged larva stage is generally related to the slower growth and low food ingestion, the possible existence of toxic allelochemicals in the plant extract or the occurrence of nutritional imbalance. The extension of the larval stage S. frugiperda was reported by Forim et al. (2010) when neem extract $\left(100 \mathrm{mg} \mathrm{kg}^{-1}\right)$ was used in an artificial diet, a meliaceous belonging to the family of $M$. azedarach .

Taking into account these results to the field conditions, the use of supercritical extract of $M$. azedarach is suggested to suppress the increase of the population of $S$. frugiperda by reducing the number of generations during the development of certain crop (Barros et al., 2010). The increase in the larva period also makes the insect more prone to be attacked by predators and parasitoids.

After the thirteenth day, some insects that had amplified the larva stage exhibited slow and irregular movements, for example, movement only in the first abdominal segments with apparent paralysis in the others. This effect is related to the inhibition of cholinesterase by substances present in the extract added to the diet. The cholinesterase inactivates the neurotransmitter acetylcholine, which is responsible for muscle contraction, thereby causing disorderly movements and lethargic and less active larvae (Breuer et al., 2003).

Another effect observed was that some larvae died due to treatments with higher concentrations $(500,1000$ and 5000 $\mathrm{mg} \mathrm{kg}^{-1}$ ) during ecdysis and failed to release the old endocuticle (Figure $3 \mathrm{~A}$ ), thus indicating that the extract caused a disturbance in the endocrine system of the larvae, thereby preventing completion of morphogenesis. This effect may be attributed to the presence of limonoids compounds in the extract, causing blockage and inhibiting the release of ecdysteroids

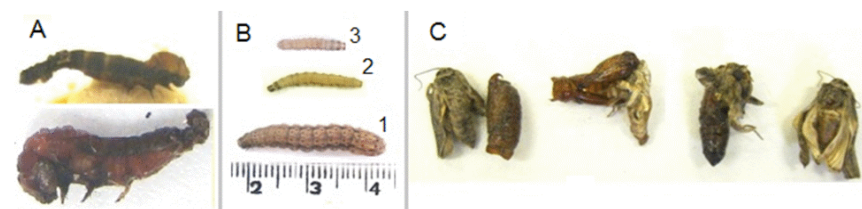

Figure 3. Adverse effects observed in Spodoptera frugiperda (Lepidoptera: Noctuidae) fed on a diet containing the $\mathrm{SC}-\mathrm{CO}_{2}$ extract of Melia Azedarach (Meliaceae). (A) Larvae killed during ecdysis. (B) Larvae control treatment (1) with normal development and larvae with low development of treatments with $1000 \mathrm{mg} \mathrm{kg}^{-1}$ (2) and $5000 \mathrm{mg} \mathrm{kg}^{-1}$ (3) of the extract. (C) Morphological deformations in an adult of treatment with $100 \mathrm{mg} \mathrm{kg}^{-1}$ of the extract

(molting hormone) responsible for the exchange process of the exoskeleton (Cespedes et al., 2013).

The supercritical extract of the fruit of $M$. azedarach not only affected the survival and duration of the larval period of $S$. frugiperda but also caused a negative effect on the body weight gain at such stage. The higher the concentration of the extract in the diet was, the lower was the body weight of the larvae, exhibiting significantly lower values than that of the control at treatment concentrations of 500, 1000 and 5000 $\mathrm{mg} \mathrm{kg}^{-1}$ (Figure 4).

At the end of the larval stage under the control treatment, at thirteen days after treatment, the reduction in weight of the larvae for treatments with higher concentrations of extract was very expressive, with a reduction higher than $92 \%$ for the treatment with $5000 \mathrm{mg} \mathrm{kg}^{-1}$ compared to the control treatment. The extract of $M$. azedarach promotes increased production of enzymes that are involved in the mechanism of the degradation of toxic substances (Breuer et al., 2003), thus redirecting energy

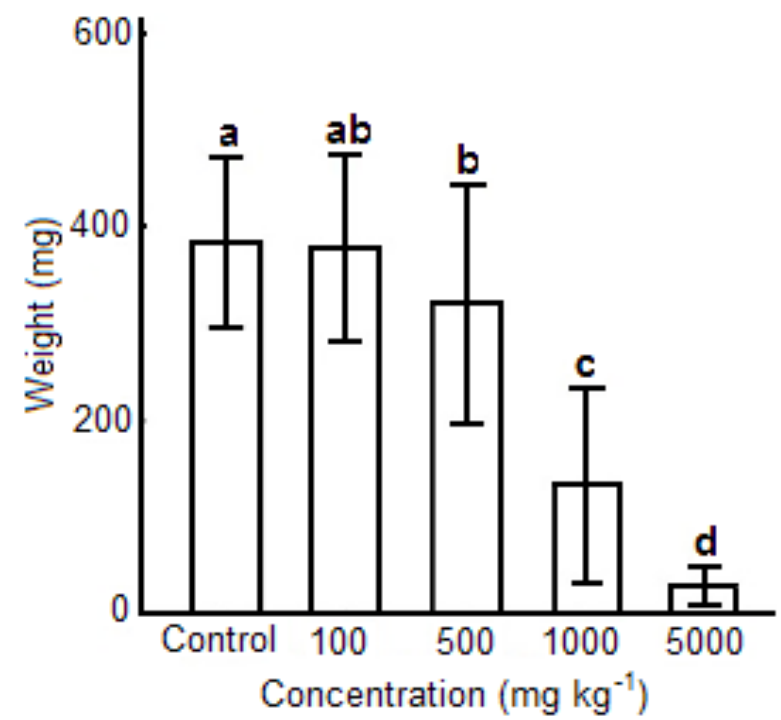

Mean with the same letter in the bars do not differ according to the Tukey test at a probability level of 0.05 .

Figure 4. Average weight $( \pm S D)$ of Spodoptera frugiperda (Lepidoptera: Noctuidae) after thirteen days feeding on a diet containing the $\mathrm{SC}-\mathrm{CO}_{2}$ extract of Melia azedarach (Meliaceae) 
Table 2. Body length of the larvae Spodoptera frugiperda (Lepidoptera: Noctuidae) fed an artificial diet containing the SC- $\mathrm{CO}_{2}$ extract of Melia azedarach (Meliaceae) from ten and thirteen days after start of the experiment (DAT)

\begin{tabular}{ccccccc}
\hline \multicolumn{2}{c}{ Concentration $\left(\mathbf{m g ~ k g}^{\mathbf{1}}\right)$} & \multicolumn{1}{c}{ Control } & $\mathbf{1 0 0}$ & $\mathbf{5 0 0}$ & $\mathbf{1 0 0 0}$ & $\mathbf{5 0 0 0}$ \\
\multirow{2}{*}{ Body length $(\mathrm{cm})$} & $10 \mathrm{DAT}$ & $2.557 \pm 0.29 \mathrm{ab}$ & $2.626 \pm 0.37 \mathrm{a}$ & $2.370 \pm 0.31 \mathrm{~b}$ & $1.840 \pm 0.43 \mathrm{c}$ & $1.192 \pm 0.30 \mathrm{~d}$ \\
& $13 \mathrm{DAT}$ & $2.975 \pm 0.30 \mathrm{a}$ & $3.050 \pm 0.33 \mathrm{a}$ & $2.824 \pm 0.38 \mathrm{a}$ & $2.159 \pm 0.49 \mathrm{~b}$ & $1.268 \pm 0.32 \mathrm{c}$ \\
\hline
\end{tabular}

Means followed by the same letter in lines do not differ according to the Tukey test at a probability level of 0.05

resources that would normally be used to gain biomass. The presence of natural products, such as flavonoids and terpenes, promote the activation of these enzymes, and components of the class of terpenes, such as triterpene melianone are also present in $\mathrm{SC}-\mathrm{CO}_{2}$ extract.

In the same way that the extract of M. azedarach caused a reduction in the larvae biomass gain of $S$. frugiperda at increasing extract concentration in the diet, this effect was also observed for the insect body length in this phase (Table 2). The low larva development is also related to the change in instar, and in treatments where insects consumed food with the extract, there were more individuals found in earlier developmental stages than in the control population (Figure $3 \mathrm{~B}$ ), which is expected to occur when the insect consumes toxic substances that inhibit their growth (Cespedes et al., 2013; Munõz et al., 2013).

The extract of M. azedarach also caused bioactive effects in the pupa stage of $S$. frugiperda, the average weight of the pupae were significantly lower in the treatments with 1000 and $5000 \mathrm{mg} \mathrm{kg}^{-1}$ in relation to the control treatment, and the average size of the pupae was significantly lower only for treatment with $5000 \mathrm{mg} \mathrm{kg}^{-1}$ (Table 3).

The pupa weight has a high correlation with the fecundity of the adults, and the reduction in fertility is one of the main effects reported in adults from pupae smaller, thus reducing the

Table 3. Pupa mass and length of Spodoptera frugiperda (Lepidoptera: Noctuidae) fed an artificial diet with the $\mathrm{SC}-\mathrm{CO}_{2}$ extract of Melia azedarach (Meliaceae) after thirteen days

\begin{tabular}{ccc}
\hline Concentration $\left(\mathbf{m g ~ k g}^{\mathbf{1}}\right)$ & Weight $(\mathbf{m g})$ & Length $\mathbf{( c m )}$ \\
Control & $384.40 \pm 87.4 \mathrm{a}$ & $3.050 \pm 0.30 \mathrm{a}$ \\
100 & $379.21 \pm 96.4 \mathrm{ab}$ & $2.975 \pm 0.33 \mathrm{a}$ \\
500 & $321.38 \pm 123.3 \mathrm{~b}$ & $2.824 \pm 0.38 \mathrm{a}$ \\
1000 & $133.19 \pm 100.6 \mathrm{c}$ & $2.159 \pm 0.49 \mathrm{~b}$ \\
5000 & - & - \\
\hline
\end{tabular}

Values followed by the same letter in columns do not differ according to the Tukey test at a probability level of 0.05 number of eggs and inhibition of postures, which is also found in insects that were fed on diets containing the plant extracts (Fantinou \& Tsitsipis, 1999). Species such as S. frugiperda consume foods of low nutritional quality during adulthood and depend on the protein reserves accumulated in the larva stage. The occurrence of sterility in these insects is usually associated with eating disorders during the larva period, which may influence the number of ovarioles per ovary and thereby reduce the potential for reproduction.

The extract also caused a reduction in pupa viability for increasing concentrations tested. In the treatment with $1000 \mathrm{mg} \mathrm{kg}^{-1}$ in a total of 40 insects, only six reached adulthood, representing $15 \%$ of the total population of treatment (Figure 5). Although the treatment with the lowest extract concentration $\left(100 \mathrm{mg} \mathrm{kg}^{-1}\right)$ led to lesser adverse effects on S. frugiperda during the larva and pupa stages, for the adult stage, this treatment resulted in the greatest quantity of adults with morphological deformities (Table 4).

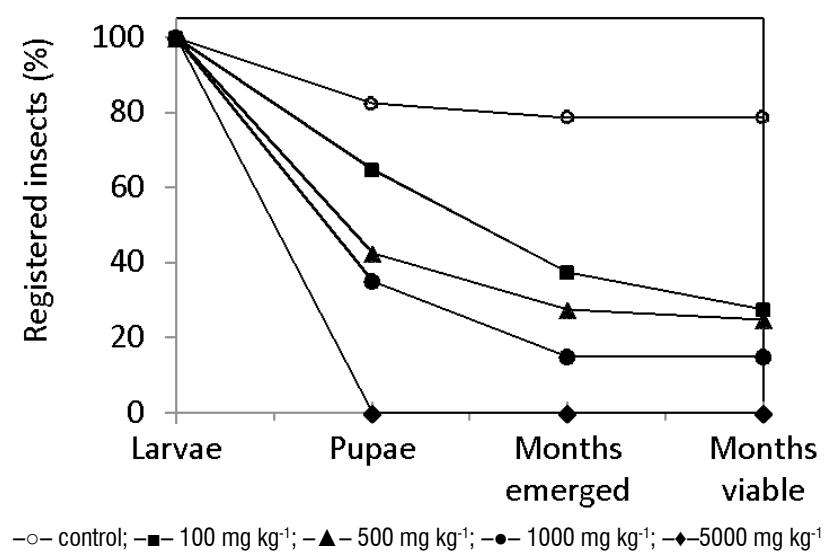

Figure 5. Percentages of the individuals recorded at each stage of the biology of Spodoptera frugiperda (Lepidoptera: Noctuidae) fed with an artificial diet containing the $\mathrm{SC}-\mathrm{CO}_{2}$ extract of Melia azedarach (Meliaceae) during the larval stage

Table 4. Percentage of the individuals at each stage of the biology of Spodoptera frugiperda (Lepidoptera: Noctuidae) fed on artificial diet with the SC- $\mathrm{CO}_{2}$ extract of Melia azedarach (Meliaceae) and the morphological deformities in adults

\begin{tabular}{|c|c|c|c|c|c|}
\hline $\begin{array}{l}\text { Concentration } \\
\left(\mathrm{mg} \mathrm{kg}^{-1}\right)\end{array}$ & $\begin{array}{c}\text { Initial number } \\
\text { of larvae }\end{array}$ & $\begin{array}{l}\text { Pupae }^{a} \\
(\%)\end{array}$ & $\begin{array}{l}\text { Emergence }^{b} \\
(\%)\end{array}$ & $\begin{array}{c}\text { Moths with morphological } \\
\text { deformities }(\%)\end{array}$ & $\begin{array}{c}\text { Total viability }^{\mathrm{d}} \\
\text { (\%) }\end{array}$ \\
\hline Control & 40 & 82.5 & 78.8 & 0.0 & 78.8 \\
\hline 100 & 40 & 65.0 & 57.7 & 26.7 & 27.7 \\
\hline 500 & 40 & 42.5 & 64.7 & 9.1 & 25.0 \\
\hline 1000 & 40 & 35.0 & 42.9 & 0.0 & 15.0 \\
\hline 5000 & 40 & 0.0 & - & - & 0.0 \\
\hline
\end{tabular}

\footnotetext{
a\% - number of pupae $\times 100 /$ total number of larvae

b\% - number of adults emerged $\times 100 /$ total number of pupae

$c \%$ - number of adults with morphological deformities $\times 100 /$ total number of adults

d\% - number of individuals that completed all stages $\times 100 /$ initial number of larvae
} 
These results indicate that the toxic effect of the extract of $M$. azedarach was manifested in different forms and phases of the biology of $S$. frugiperda. At higher concentrations, the toxic effect of the extract was still observed in the larva and pupa stages, with high mortality and feeding inhibition. The low number of adults that emerged and the morphological deformities observed for the treatment with $100 \mathrm{mg} \mathrm{kg}^{-1}$ indicate that, possibly, there was an accumulation of toxic substances in the organism of insects during the larva stage, causing a delayed bioactive effect when there was no more exposure to the extract. In this study, the observed deformations in the moths of $S$. frugiperda were malformed wings and the difficulty of the insects to free themselves from the pupal wrapper (Figure 3C).

Relating the initial number of individuals with the number of individuals who completed all stages in each treatment revealed that in no cases of the treatments with extract in the diet, the total viability at the end of the experiment was up to $30 \%$ (Figure 5).

Although the supercritical extract of fruit of $M$. azedarach did not always cause the death of the insects, the adverse effects noted, including antifeedant activity, reduced growth and mobility and deformation of pupae and adults, indicate the need for further studies toward new alternatives to control this species, for example, the interaction with other control methods, as recommended by the integrated management of insects. The main objective when using plant extracts as an insecticide is to reduce the population growth of insects, and though the mortality desired for the target species is not always achieved, the effects that it may cause on feeding, reproduction and development of the insect can of course contribute to insect control.

Despite some studies being available in the literature regarding the biological activities of $M$. azedarach on different insect species (Carpinella et al., 2006; Araújo et al., 2009), there are no reports on the insecticidal activity of the extract of $M$. azedarach obtained by $\mathrm{SC}-\mathrm{CO}_{2}$ extraction on the larvae of $S$. frugiperda; therefore, this manuscript may be the first report on the bioactive effects of such extract in this species.

\section{Conclusions}

1. The SC- $\mathrm{CO}_{2}$ extract of the fruit of $M$. azedarach caused bioactive effects on $S$. frugiperda for all concentrations tested, with distinct effects at different stages of the insect biology in relation to the concentrations tested.

2. At the lowest concentration $\left(100 \mathrm{mg} \mathrm{kg}^{-1}\right)$, the adverse effects were observed only from the adult stage of the insect, as the low viability pupa and adults exhibited morphological deformities. At the highest concentrations tested $\left(500 \mathrm{mg} \mathrm{kg}^{-1}\right.$, $1000 \mathrm{mg} \mathrm{kg}^{-1}$ and $5000 \mathrm{mg} \mathrm{kg}^{-1}$ ) adverse effects were observed during the larva and pupa stages, when the extract caused antifeedant activity, thereby interfering in the larvae and pupae weight and length that resulted in significantly lower values compared to the control treatment.

3. The extraction of $M$. azedarach with supercritical $\mathrm{CO}_{2}$ used in this study proved to be a very promising method of extraction for obtaining biologically active extracts.

\section{Acknowledgments}

The authors thank Conselho Nacional de Desenvolvimento Científico e Tecnológico ( CNPq), Coordenação de Aperfeiçoamento de Pessoal de Nível Superior (CAPES), Fundação de Apoio à Pesquisa Científica e Tecnológica do Estado de Santa Catarina (FAPESC/SC) and Ministério da Ciência, Tecnologia e Inovação - Financiadora de Estudos e Projetos (MCTI-FINEP) for the financial support and scholarships, and the researchers Dr. Paulo C. Leal and Dr. Hernán Terenzi of the Center Structural Molecular Biology Cebime of Universidade Federal de Santa Catarina - UFSC for their availability and their collaboration in the identification of the compounds.

\section{Literature Cited}

Araújo, S. A. C.; Teixeira, M. F. S.; Dantas, T. V. M.; Melo, V. S. P.; Lima, F. E. S.; Ricarte, A. R. F.; Costa, E. C.; Miranda A. M. Potencial uses of Melia azedarach L. (Meliaceae): A survey. Arquivos do Instituto Biológico, v.76, p.141-148, 2009.

Barros, E. M.; Torres, J. B.; Bueno, A. F. Oviposition, development, and reproduction of Spodoptera frugiperda (J. E. Smith) (Lepidoptera: Noctuidae) fed on different hosts of economic importance. Neotropical Entomology, v.39, p.996-1001, 2010.

Bohnenstengel, F. I.; Wray, V.; Witte, L.; Srivastava, R. P.; Proksch, P. Insecticidal meliacarpins (C-seco limonoids) from Melia azedarach. Phytochemistry, v.49, p.866-871, 1999.

Breuer, M.; Hoste, B.; Loof, A. D.; Naqvi, S. N. H. Effect of Melia azedarach extract on the activity of NADPH-cytochrome $c$ reductase and cholinesterase in insects. Pesticide Biochemistry and Physiology, v.76, p.99-103, 2003.

Brunherotto, R.; Vendramim, J. D.; Oriani, M. D. Effects of tomato genotypes and aqueous extracts of Melia azedarach leaves and Azadirachta indica seeds on Tuta absoluta (Meyrick) (Lepidoptera: Gelechiidae). Neotropical Entomology, v.39, p.784-791, 2010.

Bullangpoti, V.; Wajnberg, E.; Audant, P.; Feyereisen, R. Antifeedant activity of Jatropha gossypifolia and Melia azedarach senescent leaf extracts on Spodoptera frugiperda (Lepidoptera: Noctuidae) and their potential use as synergists. Pest Management Science, v.68, p.1255-1264, 2012.

Carpinella, M. C.; Defago, M. T.; Valladares, G., Palacios, S. M. Role of Melia azedarach L. (Meliaceae) for the control of insects and acari: Present status and future prospect. In: Carpinella, M. C; Rai, M. (ed.), Naturally occurring bioactive compounds. Amsterdam: Elsevier, 2006. p.81-123.

Cespedes, C. L.; Molina, S. C.; Muñoz, E.; Lamilla, C.; Alarcon, J.; Palacios, S. M., Carpinella, M. C., Avila, J. G. The insecticidal, molting disruption and insect growth inhibitory activity of extracts from Condalia microphylla Cav. (Rhamnaceae). Industrial Crops and Products, v.42, p.78-86, 2013. 
Defagó, M.; Valladares, G.; Banchio, E.; Carpinella, C.; Palacios, S. Insecticide and antifeedant activity of different plant parts of Melia azedarach on Xanthogaleruca luteola. Fitoterapia, v.77, p.500-505, 2006.

Dequech, S. T. B.; Egewarth, R.; Sausen, C. D.; Sturza, V. S.; Ribeiro, L. P. Action of plants extracts on oviposition and on mortality of diamondback moth. Ciência Rural, v.39, p.551-554, 2009.

Fantinou, A.; Tsitsipis, J. A. Effect of larval density on development and diapouse of Sesamia monagrioides (Lef.) (Lep., Noctuidae) under laboratory conditions. Journal of Applied Entomology, v.123, p.187-190, 1999.

Forim, M. R.; Matos, A. P.; Silva, M. F. G. F.; Cass, Q. B.; Vieira, P. C.; Fernandes, J. B. The use of HPLC in the control of neem commercial products quality: reproduction of the insecticide action. Quimica Nova, v.33, p.1082-1087, 2010.

Greene, G. L.; Leppla, N. C.; Dickerson, W. A. Velvetbean caterpillar: A rearing procedure and artificial medium. Journal Economic Entomology, v.69, p.487-488, 1976.

Harbore, J. B. Phytochemical methods: A guide to modern techniques of plant analysis. 3.ed. New York: Chapman \& Hall, 1998. p.40-138.

Heong, K. L.; Tan, K. H.; Garcia, C. P. F.; Fabellar, L. T.; Lu, Z. Research methods in toxicology and insecticide resistance monitoring of rice plant hoppers. Philippines: International Rice Research Institute, 2011. p.37-42.

Isman, M. B. Tropical forests as sources of natural insecticides. In: Romeo, J. T. (ed.). Chemical ecology and phytochemistry of forest ecosystems. Recent Advances in Phytochemistry, v.39, p.145-161, 2005.

Jacques, R. A.; Krause, L. C.; Freitas, L. S.; Dariva, C.; Oliveira, J. V.; Caramão, E. B. Influence of drying methods and agronomic variables on the chemical composition of mate tea leaves (Ilex paraguariensisA. St.-Hil) obtained from high-pressure $\mathrm{CO}_{2}$ extraction. Journal of Agricultural and Food Chemistry, v.55, p.10081-10085, 2007.

Lavie, D.; Jain, M. K.; Kirson, I. Terpenoids-V melianone from Melia azedarach L. Tetrahedron Letters, v.19, p.2049-2052, 1966.

Lee, S. M., Klocke, J. A., Balandrin, M. F. The structure of 1 -cinnamoylmelianolone, a new insecticidal tetranortriterpenoid, from Melia azedarach (Meliaceae). Tetrahedron Letters, v.28, p.3543-3546, 1987.
Munõz, E.; Lamilla, C.; Marin, J. C.; Alarcon, J.; Cespedes, C. L. Antifeedant, insect growth regulatory and insecticidal effects of Calceolaria talcana (Calceolariaceae) on Drosophila melanogaster and Spodoptera frugiperda. Industrial Crops and Products, v.42, p.137-144, 2013.

Nahar, L.; Sarker, S. D. Supercritical fluid extraction. In: Sarker, S.D.; Latif, Z.; Gray, A.I. (ed.). Natural product isolation. Methods in biotechnology. 2.ed. New Jersey: Human Press, 2006. p.47-78.

Nathan, S. S. Effects of Melia azedarach on nutritional physiology and enzyme activities of the rice leaffolder Cnaphalocrocis medinalis (Guenée) (Lepidoptera: Pyralidae). Pesticide Biochemistry and Physiology, v.84, p.98-108, 2006.

Ntalli, N. G.; Cottiglia, F., Bueno, C. A.; Alché, L. E.; Leonti, M.; Vargiu, S.; Bifulco, E.; Menkissoglu-Spiroudi, U.; Caboni, P. Cytotoxic tirucallane triterpenoids from Melia azedarach fruits. Molecules, v.15, p.5866-5877, 2010.

Pedlowski, M. A.; Canela, M. C.; Terra, M. A. C.; Faria, R. A. M. Modes of pesticides utilization by Brazilian smallholders and their implications for human health and the environment. Crop Protection, v.31, p.113-118, 2012.

Polonsky, J.; Varon, Z.; Rabanal, R. M. 21,20-Anhydromelianone and melianone from Simarouba amara (Simaroubaceae); Carbon-13 NMR spectral analysis of $\Delta^{7}$-Tirucallol-Type triterpenes. Israel Journal of Chemistry, v.16, p.16-19, 1977.

Reverchon, E.; Marco, I. de. Supercritical fluid extraction and fractionation of natural matter. Journal of Supercritical Fluids, v.38, p.146-166, 2006.

Rodrigues, M. R. A.; Krause, L. C.; Caramão, E. B.; Santos, J. G.; Dariva, C.; Oliveira, J. V. Chemical composition and extraction yield of the extract of Origanum vulgare obtained from sub and supercritical $\mathrm{CO}_{2}$. Journal of Agricultural and Food Chemistry, v.52, p.3042-3047, 2004.

Rossetti, M. R.; Defagó, M.T.; Carpinella, M.C.; Palacios, S.M.; Valladares, G. Biological activity of extracts of Melia azedarach on larvae of Spodoptera eridania (Lepidoptera: Noctuidae). Revista de la Sociedad Entomológica Argentina, v.67, p.115-125, 2008.

Wittstock, U.; Gershenzon, J. Constitutive plant toxins and their role in defense against herbivores and pathogens. Current Opinion in Plant Biology, v.5, p.300-307, 2002. 